\title{
Motives for the Social Sharing of an Emotional Experience
}

Running head: Motives for sharing an emotional experience

Christelle Duprez ${ }^{1}$, Véronique Christophe ${ }^{1}$, Bernard Rimé $^{2}$, Anne Congard $^{3}$, and Pascal Antoine ${ }^{1}$

Affiliations:

1. Lille 3 University- URECA EA 1059 (France)

2. University of Louvain, Institute of Psychological Sciences IPSY (Belgium)

3. Aix Marseille University, PsyCLE EA 3273 (France)

Correspondence should be addressed to Christelle Duprez $(\mathrm{PhD})$ or Véronique Christophe (PhD), University of Lille 3, URECA EA 1059, B.P. 60149, F-59653 Villeneuve d'Ascq Cedex - France, e-mail : christelle.duprez@univ-lille3.fr / veronique.christophe@univ-lille3.fr Phone: +33 (0)3 204167 06, Fax: +33 (0)3 20416032 


\begin{abstract}
Research has shown that people are eager to discuss their emotional experiences, regardless of their positive or negative valence. This phenomenon has been termed the "social sharing of emotions" (Rimé, 1989). The two studies that are presented in this article aimed to clarify and assess the motives underlying the propensity of humans to share their emotional experiences with others. In the first study, a large number of motives that the subjects could recall for having shared a specified emotional experience (positive or negative) was collected from 182 participants. The collected motives were submitted to content analysis and organized into 8 categories. In each of these categories, 9 representative items were preserved to create a scale of alleged motives for sharing an emotional experience. This scale was tested with 719 respondents in the second study. The 72 items that were retained from the first study underwent a factor analysis and a principal component analysis. The final structure of the Social Sharing Motive Scale (SSMS-39) includes 39 items that are organized into 7 factors: "clarification and meaning", "rehearsing", "venting”, "arousing empathy/attention", “informing and/or warning”, “assistance/support and comfort/consolation”, and "advice and solutions". The collected data provided insight into the role of the social sharing of emotions in emotion regulation: the majority of the alleged motives entail demands on others. The factor structure of the SSMS-39 appears to be consistent and reliable and may be useful in the investigation of links between sharing motives and the actual responses of targets as well as the consequences for the emotional recovery and general well-being of a person who shares such experiences.
\end{abstract}

Keywords: social sharing, alleged motives, emotion regulation 
Motives for the Social Sharing of an Emotional Experience

Traditionally, psychologists have investigated emotions as intrapersonal processes. It was stressed that emotions develop in the physiology of the individual and resonate in the depths of this individual' subjective life (e.g., Arnold, 1960; Frijda, 1986; Tomkins, 1995). However, the empirical literature of recent decades is replete with concepts emphasizing emotions as sustaining essential connections with interpersonal relationships. These concepts accent the fact that emotions are accompanied with verbal expression processes. What used to be considered as a private experience is generally put into words and communicated to members of the entourage. Thus for instance, the study of emotional disclosure addresses how people respond to emotional upheavals and why translating emotional events into language increases physical and mental health (for reviews, Pennebaker \& Chung, 2007; Smyth \& Pennebaker, 2008). Thus, whereas self-disclosure was defined as "an interaction between at least two individuals where one intends to deliberately divulge something to another" (Greene, Derlega and Mathews, 2006, p. 411), emotional disclosure represents a specific form of self-disclosure focused at the verbal expression and communication of a personal emotional experience. An important scientific interest exists for the investigation of effects of written emotional disclosure on well-being (e.g., Pennebaker, 1997; Smyth \& Pennebaker, 2008). Participants write about past stressful or traumatic events in their lives for short sessions (15 to 30 minutes) held on several consecutive days (for a meta-analytic study of effects, see Frattaroli, 2006). Co-rumination was particularly examined in the friendships of children and adolescents. It involves "extensively discussing and revisiting problems, speculating about problems, and focusing on negative feelings" (Rose, 2002, p. 1830). Corumination was related to positive friendship quality but also to elevated internalizing symptoms. Studies showed that such rehashing of one's emotions is socially reinforced and 
perpetuated by target persons and that co-rumination predicts the onset of depressive disorders during adolescence (Calmes \& Roberts, 2008; Stone, Hankin, Gibb, \& Abela, 2011). Whereas co-rumination studies examine the expression and verbalization of negative emotions and feelings, capitalization studies investigate people's propensity to share with close persons the positive emotional experience they just went through (for a review, Gable \& Reis, 2010). Capitalization occurs when one member of a relationship dyad experiences a personal event that positively affects himself or herself and then relates it to the other member of the dyad. Langston (1994) proposed the term "capitalization" after having observed that sharing the news of a positive event with others led the subject experiencing more positive affect than could be attributed to the event itself. Capitalization studies later evidenced the positive effect that sharing a positive emotion can have on the interpersonal relationship itself (e.g., Gable, Reis, Impett, \& Asher, 2004).

Besides these different concepts, studies on the social sharing of emotion were first to evidence people's propensity to share their emotional experiences. The social sharing of emotion was defined as a communication process involving the description of an emotion in a socially-shared language by the person who experienced it to another one (Rimé, Mesquita, Philippot, \& Boca, 1991). Abundant data showed that when people go through an emotional experience, they immediately feel the need to talk with members of their entourage, and they actually do so in almost all cases (for reviews, Rimé, 2009; Rimé, Finkenauer, Luminet, Zech, \& Philippot, 1998; Rimé, Philippot, Boca, \& Mesquita, 1992). Overall, emotional episodes are subject to social sharing conversations in 80 to $95 \%$ of the cases, a figure that comes close to those reported for the sharing of positive emotions in recent capitalization studies (Gable \& Reis, 2010, pp. 215-216). The social sharing of a given episode occurs most often repetitively--usually several times, with different people for a same emotional episode. The more intense the emotion is, the higher the propensity to talk about it (Luminet, Bouts, Delie, 
Manstead, \& Rimé, 2000). The sharing process typically begins early after an emotional experience has occurred. In $60 \%$ of the cases indeed, the first sharing of occurs on the actual day that the event occurred, as was also found for the specific case of positive emotions (Gable \& Reis, 2010, p. 215). Across age groups, targets of social sharing were consistently found to be intimates (i.e., parents, brothers, sisters, friends, or spouse/partner) whereas nonintimates hardly played some role in the sharing process, as was also observed for the specific case of positive emotions (Gable \& Reis, 2010, p. 216). Communicating an emotional experience seems to be a universal response to an emotion. It is observed with approximately equal magnitude in Asian and Western countries (Singh-Manoux \& Finkenauer, 2001). Episodes that involve fear, anger, or sadness, are reported to others as often as those involving happiness or love (Rimé et al., 1992). However, emotional episodes that involve shame and guilt tend to be verbalized to a lesser degree (Finkenauer \& Rimé, 1998; Rimé et al., 1998; Singh-Manoux \& Finkenauer, 2001).

An important feature is that social sharing of an emotion reactivates the shared emotion in the sharing person. Thus, related mental images are re-experienced, body sensations are felt, and subjective feelings are aroused (Rimé, Noël, \& Philippot, 1991; Rimé, 2009). In the case of negative emotions, emotional reactivation typically leaves the sharing person in an arousal state. Interestingly, despite these negative consequences, research on social sharing has shown that people are generally eager to discuss their emotional experiences, whether negatives or positives (for reviews, Rimé et al., 1998, 2009). Then, why are people so eager to share their emotions? The studies that are presented in this article aimed to clarify and assess the motives underlying the universal propensity to share both pleasant and unpleasant emotions. First, we will briefly review the theoretical concepts that are pertinent to this topic, first those for positive emotions and then those for negative emotions. 
Positive emotions result from circumstances that facilitate goal-attainment activities (Carver \& Scheier, 1990, 2001), and they enhance a subject's well-being by increasing his/her level of positive affect. Likewise, the social sharing of a past positive emotional experience is likely to elicit pleasurable emotional feelings. In two different studies, Langston (1994) confirmed that the communication of positive events to others was indeed associated with an enhancement of positive affect far beyond the benefits resulting from the valence of the positive events themselves. Gable et al. (2004) demonstrated that close relationships in which one's partner typically responds enthusiastically to such a capitalization were associated with higher relationship well-being (e.g., intimacy, daily marital satisfaction). Thus, sharing positive emotions can enhance both the positive affect of individuals and the social bonds between them (Reis et al., 2010). Therefore, capitalization and social integration constitute two demonstrated motives underlying the sharing of positive emotions.

With regard to the question of why people share negative emotional experiences, Schachter (1959) first proposed an answer in the framework of his classic "stress and affiliation" studies. He found that the participants who became anxious at the prospect of being administered electric shocks expressed a preference for waiting in the company of other persons, whereas the control participants preferred to wait alone. Schachter hypothesized that individuals encountering stress attempted to reduce their anxiety by verbally interacting with others in the same situation and thus using others as a lens through which to evaluate their own emotional state. This social comparison motive (Festinger, 1954) is especially relevant when people lack objective standards or undergo a confusing experience, which are typical characteristics of negative emotional experiences.

Negative emotional episodes undermine a person's knowledge base because these episodes disconfirm expectations and models of the world. Thus, such episodes represent a broad form of distress that a person is highly motivated to reduce (Epstein, 1973, 1990; Rimé, 
2009). Although he favored a social comparison explanation for his "stress and affiliation" effect, Schachter (1959) also considered emotional support, or direct distress reduction through the presence of others, to be involved in the process. Since the observations of Bowlby (1969) on attachment, ample evidence has shown that both primate and human infants seek contact with others during periods of uncertainty and distress (e.g., Ainsworth, Blehar, Waters, \& Wall, 1978; Sroufe \& Waters, 1976). According to Shaver and Klinnert (1982), this early form of affiliation is perpetuated among adults and serves two distinct but related functions: direct anxiety reduction and increased cognitive clarity. This contact seeking would however depend on the quality of the attachment figure's responses when proximity/help was sought during infancy and childhood, and the expectations these responses elicited about the help the others can provide when distressed in adulthood leading to interpersonal differences in attachment style and proximity seeking (Ainsworth, 1972; Shaver \& Mikulincer, 2002; for review, Cassidy \& Shaver, 2008; Mikulincer \& Shaver, 2007). Thus, the generalized distress that negative emotions produce likely motivates adults (particularly secure and insecure anxious individuals, but to a lesser extent insecure avoidant individuals - whose expectations regarding support from others are negative, for a review see Shaver and Mikulincer, 2002) to search for emotional support and to turn to their attachment figures for this purpose.

Many arguments favor the search for cognitive clarity as the primary motive for the social sharing of negative emotional episodes. By disconfirming aspects of a person's schemas, models, theories, or assumptions, negative episodes both elicit a state of emotional distress and generate a state of cognitive dissonance within an individual. Therefore, negative emotions are likely to stimulate cognitive efforts toward dissonance reduction (Festinger, 1957). This reasoning was anticipated by both Cantril (1950) and Kelly (1955), who viewed emotions as occurring in moments at which events "do not stick" with cognitive constructions 
and thus compel individuals to modify these constructions. More recently, Martin and Tesser (1989) argued that when progression toward a goal is blocked or when a discrepancy occurs between the current state of affairs and the expected situation, conditions for the development of cognitive activity are fulfilled. Similarly, Weick (1995) observed that when expectations are disconfirmed or when activities in progress are blocked, efforts to produce meaning emerge. In accordance with these theoretical propositions, a review of the previous empirical findings suggested that one of the most reliable predictors of the need to discuss an emotional episode is the extent of the cognitive needs that are aroused by a given episode (Rimé et al., 1998). Thus, when emotional experiences elicited a need to "put things in order with regard to what occurred", to "find meaning in what occurred", or to "understand what occurred", these experiences were more likely to be subsequently shared. This finding suggests that as the extent to which an emotional episode creates a subjective sense of unfinished cognitive business increases, individuals are likely to feel more motivated to discuss their emotional experiences with others. The results of studies of "secret emotions" support this view. Memories of unshared emotional episodes were found to elicit feelings of unresolved cognitive business among the respondents more so than did memories of episodes that had been shared (Finkenauer \& Rimé, 1998). Thus, a need to obtain cognitive clarity or to find meaning appears to constitute a third motive for the social sharing of negative emotion.

In sum, three major motives appear to lead people to share their negative emotional experiences: emotional comparison, emotional support and cognitive clarity concern. Naturalistic investigations of the stress and affiliation effect have also supported such a conclusion. Kulik and colleagues (Kulik, Mahler, \& Earnest, 1994; Kulik, Mahler, \& Moore, 1996) examined affiliation toward roommates among hospital patients expecting to undergo major cardiac surgery. In addition to using real life-threatening health events, the authors also assessed actual interaction patterns rather than the mere expression of intentions. In one such 
study, Kulik et al. (1994) concluded that cognitive clarity most accurately accounted for the effects on verbal affiliation that were observed. However, in a subsequent study that examined cognitive clarity concerns, emotional comparison, and emotional support, Kulik et al. (1996) found evidence for all three motives. These authors concluded that when stress and affiliation relationships were considered in more naturalistic situations, multiple reasons for interpersonal affiliation under threat emerged. This conclusion can likely be extended to the social sharing of emotion.

Another relevant source of information lies in the motives that people openly allege for engaging in sharing behavior. Three sets of data are available in this regard (for a review, see Rimé, 2007). The first set was obtained from a group of psychology students who were enrolled in an advanced class on emotion. These students first recalled a recent emotional experience that they had shared and then listed all of the possible reasons that they had engaged in sharing (Finkenauer \& Rimé, 1996). In a second study, a pool of 200 answers was collected from non-psychology students who also referred to a recent emotional experience that they had shared. Their alleged motives for sharing were then grouped by judges using the smallest possible number of classifications (Delfosse, Nils, Lasserre \& Rimé, 2004). Finally, in a third study, 100 male and female participants were recruited in university libraries, and each participant was asked to list five different reasons that they had shared a recent emotional episode in their lives (Nils, Delfosse, \& Rimé, 2005, cited by Rimé, 2007). These three studies manifested a striking consistency in the sources of motives that they evidenced. (see Table 1). Together, these studies yielded a list of twelve motivational sub-types (see Table 2). Some of these motives are essentially self-oriented, including rehearsing an episode or venting about it, whereas other motives are more clearly other-oriented, such as entertaining, informing, or warning the target. In contrast, all of the remaining motives in the list manifest considerable demands on the social targets with regard to emotion regulation. 
Social sharing partners are indeed expected to provide contributions that are as diverse as providing assistance and support, comfort and consolation, legitimization, clarification and meaning, and advice and solutions. Moreover, this long list of specific social solicitations is still augmented with less specific and more personally involving demands of sharing partners, such as providing attention, bonding, and eliciting empathy. Thus, the motives that are openly alleged for socially sharing emotions reveal an overabundance of social demands aimed at emotional regulation. Although these motives also involve cognitive regulation needs, such as the pursuit of clarification and meaning, they are overwhelmingly likely to meet socioaffective regulation needs such as the search for comfort/consolation.

Insert tables 1 and 2 here

The current studies intended to examine the interrelationship between the major classes of motives for social sharing and to construct a reliable questionnaire for the assessment of the various motives evidenced. Such a questionnaire may be useful in many different regards. For example, this type of survey would facilitate an examination of variations in motives as a function of the type of emotion that is involved in a shared episode, aspects of emotional circumstances surrounding an episode, types of target persons, and personality traits or clinical diagnoses of sharing persons. The questionnaire could also facilitate the investigation of relationships between sharing motives and the actual responses of targets, in addition to the effects on the emotional recovery and general well-being of sharing individuals. Several existing scales already aim at assessing emotional disclosure: Emotional Self-Disclosure Scale (Snell, Miller, \& Belk, 1988), Self-Disclosure Index (Miller, Berg, \& Archer, 1983), Distress Disclosure Index (Kahn \& Hessling, 2001), and Ambivalence Over emotional Expression (King \& Emmons, 1990). Yet, these scales all measure 
confiding/not confiding one's emotions as a stable individual difference. However, the reasons why people talk about their emotional experiences are determined by both the characteristics of the emotional experience (e.g., valence, type of emotional episode) and the characteristics of the individual (e.g., gender, age) (Delfosse et al., 2004). Furthermore, these existing scales mostly assess the extent of disclosure of negative emotions, thus neglecting positive ones. Having a tool allowing to measure the alleged motives for social sharing would not only permits to better identify expectations in terms of emotion regulation, but also to assess the impact of characteristics of both the individual and the event on these emotion regulation needs. The three studies which previously investigated the alleged motives for social sharing have already documented this phenomenon. Yet, they simply aimed at exploring existing social sharing motives. The present study is in line with these studies, while differing by its aims of creating a questionnaire and as a consequence by collecting data in a more exhaustive way. The present study was planned for the purpose of collecting from participants, and in participant's own colloquial verbal formulations, a large number of motives, in order to create an assessment tool made of items directly inspired from these colloquial formulations. In addition, insofar as in these previous works the alleged motives for social sharing were mainly collected from students, it seemed important to collect data from a much more varied sample of respondents.

In the first study, we collected a large the broadest possible number of motives that the respondents could identify for having shared an emotional experience with others. The collected motives were then organized into categories and transformed into items. In a second study, the resulting questionnaire was tested on a large sample of respondents.

\section{Study 1}

\section{Method}


Procedure. 240 people were contacted individually by a female investigator in university libraries, on campus, or through social networks on the internet. These individuals were invited to participate in a university investigation of the memory of emotional events by completing a questionnaire. The contacted persons who accepted were then asked to recall a recent emotional event that happened less than 3 months before and that they had personally experienced and shared with other persons. Half of the participants were randomly selected to recall a positive emotional episode, whereas the other half were asked to recall a negative emotional experience. Individuals who declined to participate or were unable to recall an emotional event that they had experienced were thanked and dismissed. Those who retrieved a memory as requested then answered the study questionnaire. Confidentiality and anonymity were guaranteed. After indicating their age and gender, the participants were first asked to provide a short written description of the emotional episodes that they had recalled. This procedure, commonly used in studies about social sharing, helps participants to reimmerse themselves in the memory of the emotional situation and to experience a reactivation of the various emotional components before answering the study questionnaire (Rimé et al., 1991).

Participants. In total, 182 participants (97 females) whose ages ranged from 18 to 79 years $(M=30.16, S D=12.08)$ completed the questionnaire, with 81 of them (43 females) in the positive emotion condition and 101 individuals (54 females) in the negative emotion condition. Nearly half of the participants were students (48.90\%), 37.91\% were employees, 9.89\% were unemployed, and $3.30 \%$ were retired. A majority of the participants were living in couples $(60.44 \%), 34.06 \%$ were single, $3.30 \%$ were living alone with children, and $2.20 \%$ were widows.

Measurements. The respondents rated the valence of these episodes on a 7-point scale ( $1=$ "not positive at all" to $7=$ "very positive") and the intensity of the distress that the episode had elicited $(0=$ "not upset at all" to $10=$ "extremely upset"). Subsequently, the 
participants responded to items that were intended to examine their sharing of these episodes: (1) with whom did they share their experiences (partner, spouse, family member, relative, or stranger), (2) how long after the events did they first share them (same day/same week/more than one week later), (3) the number of people to whom they had spoken (one or two/3 to 10/more than 10), and (4) the total number of times that they had discussed their experiences with someone (once or twice/3 to 10 times/more than 10 times). The questionnaire concluded with one question that was intended to collect a broad range of potential motives for sharing an emotion: "Please list the first 10 reasons that you can recall for discussing this episode with people around you". A prompt reading "I talked about this event because I wanted to... " was then followed by a blank space in which the participant could freely formulate up to 10 social sharing motives. This procedure allowed us to collect a wide range of alleged motives for social sharing.

\section{Results and discussion}

Emotional episodes. The reported emotional episodes were rated as moderately upsetting, both in the positive valence condition $(M=6.04, S D=1.09)$ and in the negative condition $(M=5.44, S D=1.58)$, which did not differ significantly $\left(F_{(1,180)}=1.89\right)$. Positive episodes were related to personal instances of achievement (34.57\%, e.g., "finding a job"), leisure (14.81\%, e.g., "attending a concert"), or relationships $(12.34 \%$, e.g., "falling in love"»). Negative episodes primarily involved relationship problems (15\%, e.g., "break-up"), health (15\%, e.g., "partner being hospitalized"), or experiences of defeat (14\%, e.g., "exam failure").

Social sharing. The episodes were first shared on the day that they occurred in $62.64 \%$ of cases, during the following week in $26.92 \%$ of instances, and more than one week later $10.44 \%$ of the time with no significant difference between the valence conditions $\left(\chi^{2}(2\right.$, ${ }_{182}<1.00$. The participants reported having first shared their experiences with their spouse or 
partner in $41.76 \%$ of cases, with another family member in $32.97 \%$ of instances, with a friend in $20.88 \%$ of instances, and with a relative in only $4.39 \%$ of cases. The episodes were shared with three to ten people by a majority of the participants $(54.4 \%)$, whereas $26.9 \%$ had shared their experiences with more than ten people, and only $18.7 \%$ reported having shared with only one or two persons. Positive episodes were shared with more people than negative episodes $\left(\chi^{2}(2,182)=7.58, p<.05\right)$. The frequency of social sharing was generally high: $43.96 \%$ of the respondents shared their episodes three to ten times, $32.42 \%$ shared their experiences more than 10 times, and only $23.63 \%$ shared only once or twice. Positively and negatively valenced episodes did not differ for this variable $\left(\chi^{2}(2,182)=3.46\right)$. All of the above results were perfectly consistent with previous findings regarding the basic parameters of the social sharing of emotions (for reviews, Rimé et al., 1998, 2009).

Motives for social sharing. The respondents provided a total of 514 motives for sharing the episodes that they reported, with 308 motives in the positive episode condition and 206 motives in the negative episode condition. As these figures show, positive emotional episodes elicited a much larger number of motives from the participants than did negatively valenced episodes. This difference most likely reflects the heightened creativity and broadened perspective that is observed when positive emotional memories are retrieved or, more generally, when participants are exposed to a positive mood induction (Fredrickson, 1998, 2001; Isen, 2000). Of the 182 participants, $83(n=55$ in the "negative episode" condition, and $n=28$ in the "positive episode" condition) reported two or more reasons which after analysis appeared to belong to a same class of motives.

The 514 collected motives were submitted to a content analysis (Bardin, 1991) in order to organize them into categories of motives. This analysis was led by two independent judges who were uninformed of the categorization scheme proposed by Rimé (2007). The answers that were collected were initially submitted to a semantic analysis that aimed to 
group items with similar meaning (e.g., "the need to free myself", "emotional release"). Subsequently, items with similar objectives were combined into the same category (e.g., “externalize my happiness", "venting my good mood state"). Categories that were obtained by the two judges were then compared to examine discordance. Seventeen items were ultimately eliminated because their content appeared peculiar or irrelevant to social sharing. In addition, 10 other items were discarded because the judges could not agree on how to categorize them. This data-driven categorization resulted in 8 classes of motives, which were very similar to the categorization proposed by Rimé (2007) (see Table 2). The titles of each of the categories resulting from the content analysis were adjusted in order to better correspond to those defined by Rimé (2007) (e.g., a category first entitled "informational social support" was entitled "advices and solutions" after the judges learnt the classification established by Rimé (2007).

Insert table 3 here

Table 3 lists these categories, the number and proportion of items within each category, and examples of such items. The table shows that the answers of the respondents generally corresponded to categories proposed by Rimé (2007). However, the items within the categories of "assistance and support" and "comfort/consolation" could not be meaningfully distinguished from one another. Thus, it was determined that these categories should be merged into a single category labeled "assistance, support, and comfort". A merging also occurred for "arousing empathy" and "gaining attention" which were merged into a category labeled "arousing empathy/attention". Encompassing nearly $28 \%$ of the items, "venting" accounted for the largest proportion of answers, followed by "informing and/or warning", "advice and solutions", "assistance, support, and comfort" and "arousing empathy/attention", 
each of which accounted for $10 \%$ to $20 \%$ of the collected answers. Less than $10 \%$ of the items were categorized as "rehearsing", "bonding", or "clarification and meaning". Finally, two categories, "legitimization" and "entertaining," which were present in the categorization proposed by Rimé (2007), were not represented at all in the answers of the respondents. Overall, the classes of alleged motives that result from the present study confirm with a larger and more varied sample those that emerged from the three previous studies. In addition, the collected motives show strong links between the reasons why people talk about their emotional experiences and the strategies they initiate in order to regulate their emotions (e.g., searching for meaning).

"Venting", the most frequently observed motive in these data, is consistent with the common belief that discussing an emotional experience will reduce or even eliminate its emotional load (Nils \& Rimé, 2012; Rimé, 2009; Zech \& Rimé, 2005). Thus, the data show that the motives that were considered in this study were those that the respondents recalled. However, some motives might be only weakly accessible to awareness, some motives might even fail to be recalled, and some motives might be completely inaccessible to the mind. We also should acknowledge that some motives may purposely not be reported either because of social desirability concerns or simply because there are motives that are inaccessible to the mind.

Positively and negatively valenced episodes were then compared for the occurrence of the various categories of motives, and the results of this comparison are displayed in Table 4. Positive episodes were more frequently shared for purposes of "rehearsing", "arousing empathy/attention", or "informing and/or warning", whereas negative episodes were more frequently shared for purposes of "venting", "assistance, support and comfort, consolation", "clarification and meaning", or "advice and solutions". These findings are consistent with the literature on emotional regulation, which indicates that regulation needs differ according to 
whether an emotion is positive or negative (Gross \& Thompson, 2007; Koole, 2009). After a positive emotions, people predominantly want to amplify the pleasantness that is felt (upregulation), whereas after a negative emotion they are in need of cognitive and emotional assistance to gain control over this emotion (down-regulation). No difference occurred between the two types of episodes in the frequency of the "bonding" motive.

Insert table 4 here

A final version of the item list was obtained by eliminating items in each of the categories of motives that were redundant or lacked clarity and by keeping only the most representative items in each category. In each category, a total of 9 items that were representative of the category to which they belonged were preserved. The 72 resulting items were organized in random order and thus constituted the Social Sharing Motives Scale (SSMS), which was then tested in Study 2. Whereas in the first study, participants referred to either a negative or a positive emotional experience, in this second study it was decided to collect the data in reference to emotion categories rather than to emotional valence. We adopted the four emotion categories that were common to classic research on emotional expression (see Ekman, Friesen, \& Ellsworth, 1972) and emotional experience (Scherer, Wallbott, \& Summerfield, 1986; Shaver, Schwartz, Kirson, \& O'Connor, 1987): joy, anger, sadness, and fear.

\section{Study 2}

\section{Method}

Participants. In Study 2, 770 participants (245 males, 525 females) were invited to participate in a study about the emotions. They were asked to recall a recent emotional event that they personally experienced, before completing a questionnaire. The participants were randomly 
distributed in one of the four conditions. A quarter of the participants was randomly assigned to recall an event of joy, another quarter had to recall an event of sadness, and the two others quarters were recalled an event of fear or an event of anger. Overall, the participants had shared their emotional events in more than $93.4 \%(n=719$ out of 770$)$ of cases. The data from those 719 participants were then taken into account in the analyses reported hereafter. There were 193 participants in the joy condition $(M$ age $=19.55, S D=2.97 ; 62.7 \%$ females $)$, 166 in the sadness condition $(M$ age $=18.8, \mathrm{SD}=2.78 ; 70.5 \%$ females $), 167$ in the fear condition $(M$ age $=19.18 ; S D=2.83 ; 73.6 \%$ females $)$, and 193 participants in the anger condition $(M$ age $=18.5, S D=2.95 ; 69.9 \%$ females $)$. The majority of participants were college $(n=443,57.53 \%)$ or university students $(n=327,42.47 \%)$.

\section{Measurements}

Manipulation check. The participants first rated the emotional valence of the event that they had experienced on a 7 -point scale $(1=$ "not negative at all" to 7 = "very negative") and then rated the intensity of their subjective emotion on a 10-point scale from $1=$ "not upset at all" to $10=$ "very upset". The respondents then evaluated the primary emotions that they had felt in this situation by rating each of four primary feelings (anger, joy, fear, and sadness) on a 7-point scale (not at all/very strong).

Social sharing. The participants were asked if they had spoken to other person(s) about the episode. Answers were collected for five successive items: (a) yes or no; (b) if yes, how long after the emotional event did you discuss it for the first time? (the same day/the same week/more than a week later); (c) with whom did you discuss the event? (partner/friend/family/relative); (d) how often did you discuss it? (once or twice/three to four times/five or more times); and (e) with how many people did you discuss it? (1 to $2 / 3$ to $4 / 5$ or more). 
Social Sharing Motive Scale (SSMS). The SMSS began with the instruction "We would like you to report the reasons that you shared this episode with other people. To this end, please rate the following propositions by indicating how much you agree or disagree with each of them $(1=$ not at all; $7=$ very much $) "$. The participants then rated the 72 items of social sharing motives on the SSMS resulting from Study 1.

\section{Results and discussion}

Manipulation check. As expected, the participants who recalled a negative social sharing situation (anger: $M=5.75, S D=1.50$; sadness: $M=5.70, S D=1.71$; fear: $M=5.59$, $S D=1.88$ ) reported that these events were more negative than those in the positive condition (joy: $M=1.48, S D=1.18 ; F_{3,715}=335.82, p<.001$ ). Experienced emotions were congruent with the assigned condition, with a high level of anger in the anger condition $(M=6.19, S D=$ 1.16), of sadness in the sadness condition $(M=5.37, S D=1.69)$, of fear in the fear condition $(M=4.98, S D=1.94)$ and of joy in the joy condition $(M=6.22, S D=1.10)$. Moreover, the intensity of the recalled emotional episodes was generally high, with $M=8.37(S D=1.37)$ in the joy condition, $M=7.63(S D=1.73)$ in the anger condition, $M=7.82(S D=1.86)$ in the fear condition, and $M=8.18(S D=1.96)$ in the sadness condition.

Parameters of social sharing. The participants initiated this sharing on the day that the episodes occurred in $70.74 \%$ of cases, during the same week in $25.24 \%$ of instances, and more than a week later in $4.02 \%$ of cases. The latency of sharing initiation varied across conditions $\left(F_{(3,715)}=3.25, p<.05\right)$. Joyful events were shared more rapidly $(M=1.25, S D=$ $0.47)$ than sad events $(M=1.40, S D=0.62)$ or angry events $(M=1.40, S D=0.58)$. Overall, social sharing occurred once or twice in $26.33 \%$ of cases, three to four times in $26.62 \%$ of instances, and five or more times in $47.05 \%$ of instances. The respondents in the joy condition discussed their episodes more recurrently $(M=2.47, S D=0.70)$ than did the respondents in the anger condition $(M=2.05, S D=0.82)$ or fear condition $\left(M=2.04, S D=0.86 ; F_{(3,715)}=\right.$ 
$12.35, p<001)$. The number of social sharing partners amounted to one or two in $2.77 \%$ of cases, three to four in $26.77 \%$ of cases, and five or more in $70.46 \%$ of instances. The participants in the joy condition shared with more persons $(M=2.88, S D=0.33)$ compared with those in the other three conditions: anger $(M=2.54, S D=0.57)$, fear $(M=2.64, S D=$ $0.56)$, or sadness $\left(M=2.64, S D=0.55 ; F_{(3,715)}=15.55, p<.001\right)$. The social sharing partners were an intimate in $94.04 \%$ of cases (companion: $22.75 \%$, family member: $31.90 \%$, friend: $39.39 \%$ ) or an acquaintance in $5.96 \%$ of cases. This pattern was independent of event valence $\left(F_{(3,715)}=0.50, p>1\right)$. These results were consistent with those of previous studies and existing literature about social sharing (e.g., Rimé et al., 1998, 2009).

Social Sharing Motive Scale. The analysis of the ratings of the respondents on the SSMS was completed in two steps. First, the correlation matrix for the 72 items was inspected, and redundant items were eliminated to avoid generating spurious factors. Item distributions were inspected to eliminate skewed items that were likely to bias the factor analysis. Finally, a preliminary factor analysis was conducted to identify items failing to load onto any factor. In a second factor analysis, the remaining items were re-analyzed and refined until a satisfactory factor structure was obtained.

Item analysis. The $72 \times 72$ correlation matrix was inspected to detect potential redundancies $(\mathrm{r}>0.60)$. A semantic analysis showed an absence of redundancy in the majority of cases. However, five pairs of items were determined to be similar; thus, one item was removed from each pair. Second, the item distributions were examined (Gorsuch, 1997) for skewness and kurtosis. The item distributions were examined following Kendall and Stuart (1958). In the purpose of factorial analysis, Kline (1998) states that nonnormality is not problematic unless skewness $>3$ and kurtosis $>10$. In this study items which had response distributions with high skewness (approaching 3.0), and high kurtosis (greater than 7.0) were eliminated, which is slightly more severe than suggested by Kline. In 
exploratory analyses, factor loadings are generally considered to be meaningful when they exceed .40 (Floyd \& Widaman, 1995). If an item or items fail to have any substantially high loadings on any factor, these items may be deleted from the analysis and the factor analysis may be recomputed on the remaining subset of items (Floyd \& Widaman, 1995). Simple structure is achieved when each factor is represented by several items that each load strongly on that factor only (Pett, Lackey, \& Sullivan, 2003). Tabachnick and Fidell (2001) suggest that the secondary loading (or cross-loading) should be no greater than .32. Beavers et al. (2013) states the requirement of having a difference between highest loading and other loadings greater than 0.3 but this rule is very strong, mostly available for cognitive constructs and we take 0.2 as final criterion. Two items had high skewness (greater than 3.0) and kurtosis (greater than 7.0) and were thus eliminated, as highly skewed items can significantly bias the results of factor analyses (Lyne \& Roger, 2000). In total, this item analysis resulted in a loss of 7 items.

Factorial refinement. During the second phase, the questionnaire was re-analyzed. In order to investigate its factorial structure, the data were submitted to an exploratory factor analysis (EFA) with SPSS 18 and then to a confirmatory factor analysis (CFA) with LISREL 8.8 software (Jöreskog \& Sörbom, 2001). The exploratory factor analysis (EFA) was conducted on a random sample of 382 participants and the confirmatory analysis (CFA) on a sample of 387 participants.

$\boldsymbol{E F A}$. The responses to the remaining 65 items were subjected to a common factor analysis using the principal axis factoring method of extraction and Oblimin oblique rotation to allow for correlations among factors. To obtain an understandable, parsimonious, and stable structure, we defined the selection criteria to determine which items should be included in each factor. To be included, an item must have satisfied the following requirements: the highest loading needed to be above 0.40 , the loadings on the other factors needed to be below 
0.30 , and the difference between the highest loading and the other loadings needed to be greater than 0.20. After the analysis of the factor loadings and iterative eliminations of items that did not fulfill the selection criteria, 39 items remained and were organized into seven factors that explain $66.7 \%$ of the total variance (Table 5). The translation of these items is presented in Appendix 1.

$\boldsymbol{C F A}$. The results of this analysis generally suggest a good model fit $\left(\chi^{2}(387)=\right.$ 1789.95; dll=671; $p<0.001 ; \mathrm{RMSEA}=0.0661 ; \mathrm{GFI}=0.81 ; \mathrm{NFI}=0.94)$. The remaining 65 items were subjected to a principal component analysis using pair-wise missing data deletion, which yielded 720 valid cases. Three methods were employed to estimate the optimal number of components to be retained: the scree test (Cattell, 1966), Kaiser-Guttman's criterion (Kaiser, 1961), and component representativeness. The Kaiser criterion generally leads to overestimation of the number of dimensions (Tzeng, 1992), and the scree test is a rather subjective evaluation that can also slightly overestimate the number of factors (Zwick \& Velicer, 1986). The representativeness of each component after rotation gives the number of non-negligible dimensions. Eleven factors had an eigenvalue above 1 (Kaiser criterion), and the shape of the eigenvalue curve suggested that seven components should be retained (scree test). Moreover, examinations of the eight- and seven-component solutions consistently indicated that only seven components had at least three loadings above 0.40 . Thus, a sevendimensional structure was retained.

Insert table 5 here

Factor 1 "clarification and meaning" (6 items) comprises the various strategies that are intended to achieve an understanding of an emotional experience and to assign meaning to it. Factor 2 "rehearsing" (5 items) refers to a person's willingness to re-experience an emotion, 
memorize it, recall it, and even amplify it through rehearsal. Factor 3 "venting" (6 items) reflects a desire to reduce the emotional weight that is associated with an experience. Factor 4 "arousing empathy/attention" (7 items) covers the various strategies that are developed to describe emotions to listeners and elicit their sympathy. Factor 5 "informing and/or warning" (5 items) represents the intention to lend one's own experience to others for their benefit. Factor 6 "assistance/support and comfort/consolation" (5 items) reflects the willingness to obtain some form of emotional support. Finally, Factor 7 "advice and solutions" (5 items) represents the pursuit of intellectual and/or practical support.

Scores for the seven subscales were calculated by averaging the ratings of the respondents for the various items involved. Cronbach's alpha coefficients were then used to assess the internal consistency of the subscales. As shown in Table 6, the internal consistency of the six subscales ranged from 0.75 to 0.92 , and the correlations among the subscales were satisfactory.

Insert table 6 here

The influence of event valence on social sharing motives. The motives for the social sharing of emotion varied across emotional conditions (see Table 7). Overall, the motives for sharing a positive event (joy) differed significantly from those for sharing a negative event (anger, fear or sadness). Compared with negative events, positive experiences were shared more frequently for the purposes of re-experiencing the event and arousing empathy/attention, and less frequently for the purposes of venting and seeking understanding, support and advice. There were also numerous differences in alleged motives between the various types of negative episodes (implying anger, fear or sadness); thus, the discriminative power of the SSMS was confirmed. 
Insert table 7 here

Impact of gender on the alleged motives for social sharing. As shown in Table 8, all the alleged motives for social sharing were influenced by gender. Women reported more than men talking about their emotional experiences for making sense of their emotional experience, venting, seeking help/support, and obtaining advices/solutions. Men confided themselves more in order to relive the event, elicit empathy/attention, and to inform/warn others.

Insert table 8 here

Links between the social sharing parameters and the alleged motives for social sharing.

The links between the emotional intensity of the event, the characteristics of the social sharing (delay, frequency, number of sharing partners), and the 7 categories of alleged motives for social sharing are shown in Table 9. This correlation matrix clearly demonstrates the discriminative power of the SSMS39, as each of the four parameters of social sharing appears to be linked to a specific pattern of alleged motives. Regarding the relationship between the type of partner the episode was confided to for the first time and the reasons why social sharing was undertaken, it appears that seeking help/support and venting are not undertaken to the same extent depending on the type of sharing partner (Table 10). 
Insert tables 9 and 10 here

\section{General discussion}

The purpose of the current studies was to construct a reliable questionnaire to assess the major classes of motives for the social sharing of emotion. In the first study, we collected a large number of motives that the respondents could identify for having shared a personal emotional experience with others. Subsequently, the collected motives were organized into categories and converted into items to create the intended questionnaire of alleged motives for sharing an emotional experience. In the second study, this questionnaire was tested on a larger sample of respondents. We will first examine how far our findings were consistent with the results of the literature on the social sharing of emotion. We will then discuss the comparability of our findings regarding social sharing motives with those of the three existing studies that investigated this question. Next, we will comment on the motives that prevailed in our respondents' answers and on the instrument that was created in the present study to assess such motives in a systematic way in the future. Finally, we will discuss the findings resulting from our first empirical use of this instrument, in the comparison of motives according to type of emotions on the one hand and according to respondents' gender on the other hand.

Did the data reported by our respondents in relation to the social sharing of emotional episodes confirm previous observations regarding the social sharing of emotion? The results of our two studies in this respect were largely consistent with those of previous published studies. In particular, emotional episodes were predominantly found to be socially shared within a short delay. In total, these episodes had been shared on the same day that they occurred $63 \%$ and $73 \%$ of the time in Studies 1 and 2, respectively, each of which is close to 
the value of $60 \%$ that has typically been reported in previous studies (for a review, see Rimé, 2009). The major traits of the social sharing of emotion were also confirmed by our findings, which indicate that the reported episodes had been modally shared several times with several persons and that these persons were nearly always individuals with whom the respondents reported having close relationships, such as friends, companions, spouses, or family members (e.g., Rimé et al., 1998, 2009; Skowronski, Gibbons, Vogl, \& Walker, 2004). The fact that in Study 1, less participants $(54.4 \%)$ had talked about their emotional experience to a large number of persons than was the case in Study 2 (70.46\%) likely results from the difference in the intensity of the emotional episodes collected in the two studies $(M=2.10$ for moderate intensity events in Study 1 versus $M=8.00$ for more intense events in Study 2, it is indeed well established that the more the experienced event was emotionally intense, the more people talk about it (Luminet et al., 2000; Rimé et al., 1998).

How consistent were our findings on motives for the social sharing of emotion with regard to preexisting studies? Eight of the twelve classes of motives that were proposed by Rimé (2007) were confirmed by the open answers that were provided by our participants. The motives that did not emerge from these answers were «legitimization » (i.e., receiving approval, being legitimized, being understood) and «entertaining » (i.e., amusing another person). However, these two classes of motives partially overlapped with the motives of "clarification and meaning" and "gaining attention", respectively. In addition, the motives of "emotional social support" and "gaining attention and empathy" became broader categories, with "assistance, support and comfort/consolidation" in one category and "arousing empathy/gaining attention" in the other category. The results of the present study are also similar to those of the three preceding studies on alleged motives (see Table 11). The results of this study thus confirm the data from the three previous studies (Delfosse et al, 2004; Finkenauer \& Rimé, 1996; Nils et al., 2005, cited by Rimé, 2007) with a sample whose 
average age is higher $(M=30, S D=12.08$, Study 1$)$. In addition, in our sample there was as many women as men, and as many students as salaried employees (Study 1). Now, insofar as it is well established that the emotion regulation needs evolve according to age and gender, having a heterogeneous sample in terms of age and gender constitutes an undeniable contribution to the existing data.

Insert table 11 here

In our data, the most popular motives were those that involved the notion of venting (i.e., expressing one's emotion and relieving an emotional load), which was immediately followed by motives that were oriented toward listeners: "informing and/or warning", "arousing empathy/attention", "assistance, support and comfort, consolation", and "advice and solutions". In our discussion of Study 1, we emphasized that "venting" corresponded to the common belief that emotional expression reduces the intensity of emotions or resolves them completely (for a critique, see Nils \& Rimé, 2012). The next most popular motives that were mentioned above involve the expectation of an active contribution of the social sharing target to the emotion regulation process of the narrator. These expected contributions can take either a cognitive form, such as assistance in search for meaning, or a socio-emotional form, such as emotional social support and manifestations of empathy (Rimé, 2007). The importance of interpersonal relationships in emotional sharing motives is also evidenced by the presence of the motive of "help/support and comfort/consolation". This evidence indicates that the social sharing of emotion is not only primarily addressed to close persons with important demands for assistance in the emotion regulation process; this sharing also occurs with the open purpose of strengthening pre-existing social ties. As was already stated earlier, 
we insist that the motives considered in the reported studies were restricted to those that respondents recalled. Obviously, some motives may be inaccessible to the mind. Despite this caveat, collecting self-report data about motives for social sharing of emotions means identifying the reasons why, according to them, people talk about their emotional states. Consequently, it provides relevant information on the needs people experience after an emotion and that they feel as central in their interpersonal emotional verbalization.

The SSMS-39 that was developed in the present studies was both consistent and reliable. Future research should aim to verify the psychometric proprieties of this scale among larger and different populations. Most of the participants in Study 2 were women, and the respondents were quite young. This characteristic of the sample could limit the generalization of our results. Future studies will thus have to confirm the psychometric properties of this scale with a more representative sample, and to investigate the divergent and predictive validity of this tool. Also, due to the fact the SSMS-39 should differ from the existing measures of disclosure (amongst others because not focusing on negative emotions and not considering the reasons for confiding as a fixed characteristic but rather as determined by the characteristics of the emotional experience (e.g., valence, type of emotional episode) and of the individuals (e.g., gender, age), its divergent validity with such existing scales will be investigated in future studies. The scale developed in the current study offers a new tool for research that is intended to provide insight into the social dimensions of emotional regulation. In particular, the SMSS-39 will facilitate investigation of the relationships between motives and expectations that are manifested by a narrator, the manner in which listeners respond, and the consequences of such interaction on the various types of benefits that emotional sharing can provide (e.g., Badr \& Taylor, 2008; Banthia et al., 2003). Future research in this direction is likely to provide new insight into the manner in which regulation processes and the social regulation of emotions complement one another. Since emotion regulation skills are evolving 
with age (Carstensen, Fung, \& Charles, 2003; Charles \& Carstensen, 2007), it is likely that the alleged motives also change with age. Although this could not be shown in our study due to the homogeneity of age in our sample, future studies would have to investigate the impact of this variable. Having a scale which evaluates the alleged motives for social sharing then allows to better understand the emotional regulation needs the individuals search to fulfil when they talk about their emotions with their close relatives, and more generally the interpersonal side of emotion regulation.

The data collected with the SSMS-39 led to two comparisons offering an opportunity to test the capacity of this new tool to reveal differences in respondents' alleged motives for social sharing. A first comparison regarded the type of emotion (joy, fear, anger, or sadness) respondents had to refer to. Paying attention to these four emotions (joy, fear, anger, sadness) in particular was justified by the fact that they are easily identifiable, what ensured us that the participants in each condition would report an event related to the emotion cited. This variable was found to determine markedly the reasons for sharing (study 2). Thus, compared with the sharing of negative episodes, the social sharing of episodes of joy is more motivated by a desire to revive such an event by discussing it and to elicit empathy/attention. These findings are coherent with those from the capitalization studies. Gable et al. (2004) have indeed shown that sharing positive experiences within the couple not only results in intra-individual benefits (increased well-being and positive affects by the pleasurable sensations associated with the evocation of the episode), but also in inter-individual benefits. In particular, these studies show that socially sharing positive events even more strengthens the relationship when the listener responds in an empathically way (Gable et al., 2004). As evidenced by Gable and Reis (2010), talking about one's positive emotions to an empathic listener increases the appreciation and confidence that we have in this person (interpersonal benefits). In the light of these studies on "capitalization", it thus seems logical that individuals 
look for partners' empathy after they experienced positive emotions, since this type of reaction will draw both intrapersonal and interpersonal benefits. In the same way, the findings pertaining to the negative emotions are not surprising. Negative emotional episodes are shared more frequently for the purpose of finding meaning and seeking distress-buffering attitudes and actions from others. However, differences emerged according to whether the emotional episodes involved sadness, anger, or fear. Emotional episodes of sadness or anger are more frequently shared to obtain counsel from others than are episodes of fear. The data that allowed the construction of the questionnaire were collected on respondents' emotions distinguished by their valence in the first study (positive and negative emotions) or by their category in the second one (joy, anger, fear, sadness). The question then arises whether the scope of the questionnaire constructed in this manner is limited to these particular emotions or if it extends to the whole realm of emotions. In fact, we have stressed that the different social sharing motives evidenced in our work largely overlapped those that emerged from Rimé's (2007) review of the sharing motives recorded in the three previous studies on alleged motives for social sharing. In these studies, participants were instructed to refer to "an emotion that they had experienced recently and of which they had spoken". They thus referred to an emotional experience they themselves had selected, a selection procedure that allowed collecting a large variety of emotional experiences. The overlap between the reasons highlighted in these studies and those that emerge from the present work constitutes an important argument in favor of the generality of the scope of our questionnaire. Future studies will refine these preliminary data, by investigating the impact of other types of emotions on the alleged motives.

The second comparison conducted with the new SSMS-39 demonstrated that males and females respondent differ significantly_and sometimes at very high levels of significance--in their level of endorsement of all seven assessed motives of social sharing. In 
comparison to men, women reported sharing emotions much more often for the purpose of venting their feelings, for receiving help and comfort, for obtaining advice and solutions and for understanding their emotions. By contrast, men express their emotions much more in order to reexperience the episode, to arouse empathy or attention, and to inform people around them. In sum, after an emotional episode, women experience needs that are different from those experienced by men. It has already been argued that emotional regulation strategies depend on gender (e.g., Haga, Kraft, \& Corby, 2009; Zlomke \& Hahn, 2010). In particular, Haggard, Robert and Rose (2011) argued that compared to women, men are more inclined to see problem-talk as a puzzle to be solved. This is suggesting that males and females have complementary ways of discussing emotional experiences. Indeed, social sharing theory proposed that two different social sharing modes can be adopted after an emotion and that each mode is having specific consequences for the regulation of the emotion (Nils \& Rimé, 2012; Rimé, 2007, 2009). The cognitive mode takes place when the social sharing involves cognitive work, with distancing, perspective taking, reframing and reappraisal of the episode. This mode favoring the processing of the emotional experience is proper to bring emotional recovery, or a significant reduction of the impact of the episode's memory. The socio-affective mode provides the narrator with social responses involving help, support, comfort, consolation, legitimization, attention, bonding, and empathy perspective. In contrast to the previous one, this mode does not bring emotional recovery, but well a strong but temporary alleviation and feeling of relief. The socio-affective mode may usefully pave the way to the more demanding cognitive mode. The underlying rationale of this two-mode view is that as long as the cognitive appraisal of a past emotional episode remains unchanged, the memory of this episode necessarily triggers the same emotional state as the one experienced initially (Rimé, 2007). Experimental findings by Lepore, Fernandez-Berrocal, Ragan and Ramos (2004) and by Nils and Rimé (2012) provided support for the two-mode 
view. In the framework of such concepts, the gender differences evidenced here are suggesting that the social sharing motives of males and females are complementary. It should be reminded that at adult age, in both genders, the predominant sharing partners are the spouses (e.g., Rimé et al., 1998). These findings definitely call for future work on the way males and females on the one hand, and members of couples on the other hand do mutually regulate their emotions in the social sharing process. In any case, the strong and consistent differences evidenced in social sharing motives of males and females prove that the new scale developed in the reported studies is capable of evidencing new and heuristic findings. 


\section{REFERENCES}

Ainsworth, M. D. (1972). Attachment and dependency: A comparison. In J.L. Gewirtz (Ed.), Attachment and dependency (pp. 97-137). Washington: V.H. Winston.

Ainsworth, M. D., Blehar, M., Waters, E., \& Wall, S. (1978). Patterns of attachment: A psychological study of the strange situation. Hillsdale, NJ: Erlbaum.

Arnold, M. B (1960). Emotion and personality. New York: Columbia University Press.

Badr, H., \& Taylor, C. L. C. (2008). Effects of relationship maintenance on psychological distress and dyadic adjustment among couples coping with lung cancer. Health Psychology, 27(5), 616-627.

Banthia, R., Malcarne, V. L., Varni, J. W., Ko, C. M., Sadler, G. R., \& Greenbergs, H. L. (2003). The Effects of Dyadic Strength and Coping Styles on Psychological Distress in Couples Faced with Prostate Cancer. Journal of Behavioral Medicine, 26(1), 31-52.

Bardin, L. (1991). L'analyse de contenu. Paris : Presses Universitaires de France.

Beavers, A., Lounsbury, J., Richards, J., Huck, S., Skolits, G., \& Esquivel, S. (2013). Practical considerations for using factor analysis in educational research. Practical Assessment, Research, and Evaluation Online, 18, 1-14.

Bowlby, J. (1969). Attachment and loss: Vol. 1. Attachment. New York: Basic Books.

Calmes, C. A., \& Roberts, J. E. (2008). Rumination in interpersonal relationships: Does corumination explain gender differences in emotional distress and relationship satisfaction among college students? Cognitive Therapy and Research, 32(4), 577590.

Cantril, H. (1950). The why of man's experience. New York: Mac Millan.

Carstensen, L. L., Fung, H. H., \& Charles, S. T. (2003). Socioemotional Selectivity Theory and the Regulation of Emotion in the Second Half of Life. Motivation and Emotion, 27(2), 103-123. 
Carver, C.S, \& Scheier, M. (2001). On the self-regulation of behaviour. Cambridge: Cambridge University Press.

Carver, C S., \& Scheier, M. (1990). Origins and functions of positive and negative affect: A control-process view. Psychological Review, 97(1), 19-35.

Cassidy, J., \& Shaver, P. R. (2008). Handbook of attachment: Theory, research, and clinical applications (2nd ed.). New York: Guilford Press.

Cattell, R. B. (1966). Handbook of multivariate experimental psychology. Chicago: Rand McNally.

Charles, S. T., \& Carstensen, L. L. (2007). Emotion regulation in aging. In J. J. Gross (Ed.), Handbook of emotion regulation (pp. 307-327). New York: Guilford.

Delfosse, C., Nils, F., Lasserre, S., \& Rimé, B. (2004). Les motifs allégués du partage social et de la rumination mentale des émotions: Comparaison des épisodes positifs et négatifs [Alleged motives for social sharing and mental rumination of emotions: A comparison of positive and negative episodes]. Cahiers Internationaux de Psychologie Sociale, 64, 35-44.

Ekman, P., Friesen, W.V., \& Ellsworth, P. (1972). Emotion in the human face: guide-lines for research and integration of findings. New York: Pergamon Press.

Epstein, S. (1973). The self-concept revisited: Or a theory of a theory. American Psychologist, 28(5), 404-416.

Epstein, S. (1990). Cognitive-experiential self-theory. In L. Pervin (Ed.), Handbook of personality: Theory and research (pp. 165-192). New York: Guilford Press.

Festinger, L. (1954). A theory of social comparison processes. Human Relations, 7, 117-140.

Festinger, L. (1957). A theory of cognitive dissonance. Stanford University Press.

Finkenauer, F., \& Rimé, B. (1996). [Motives for sharing emotion]. Unpublished raw data. 
Finkenauer, C., \& Rimé, B. (1998). Socially shared emotional experiences vs. emotional experiences kept secret: Differential characteristics and consequences. Journal of Social and Clinical Psychology, 17, 295-318.

Floyd, F. J., \& Widaman, K. F. (1995). Factor analysis in the development and Research refinement of clinical assessment instruments. Psychological Assessment, 7, 286-299.

Frattaroli, J. (2006). Experimental disclosure and its moderators: A meta-analysis. Psychological Bulletin, 132(6), 823-865.

Fredrickson, B. L. (1998). What good are positive emotions? Review of General Psychology, New directions in research on emotion, 2(3), 300-319.

Fredrickson, B. L. (2001). The role of positive emotions in positive psychology: The broadenand-build theory of positive emotions. American Psychologist, 56(3), 218-226.

Frijda, N. H. (1986). The emotions. Cambridge University Press.

Gable, S. L., \& Reis, H. T. (2010). Chapter 4 - Good News! Capitalizing on Positive Events in an Interpersonal Context. In Mark P. Zanna (Ed.), Advances in Experimental Social Psychology (Vol. 42, pp. 195-257). Academic Press.

Gable, S. L., Reis, H. T., Impett, E. A., \& Asher, E. R. (2004). What Do You Do When Things Go Right? The Intrapersonal and Interpersonal Benefits of Sharing Positive Events. Journal of Personality and Social Psychology, 87(2), 228-245.

Gorsuch, R. L. (1997). Exploratory factor analysis: Its role in item analysis. Journal of Personality Assessment, 68(3), 532-560.

Greene, K., Derlega, V.J., \& Mathews, A. (2006). Self-Disclosure in Personal Relationships. In A.L. Vangelisti \& D. Perlman (Eds.), The Cambridge handbook of personal relationships (pp. 409-427). New York, US: Cambridge University Press.

Gross, J. J., \& Thompson, R. A. (2007). Emotion Regulation: Conceptual Foundations. In J. J. Gross (Ed.), Handbook of emotion regulation (pp. 3-24). New York: Guilford Press. 
Haga, S. M., Kraft, P., \& Corby, E.-K. (2009). Emotion regulation: Antecedents and wellbeing outcomes of cognitive reappraisal and expressive suppression in cross-cultural samples. Journal of Happiness Studies, 10(3), 271-291.

Haggard, D. L., Robert, C., \& Rose, A. J. (2011). Co-rumination in the workplace: Adjustment trade-offs for men and women who engage in excessive discussions of workplace problems. Journal of Business and Psychology,26, 27-40.

Isen, A. M. (2000). Some perspectives on positive affect and self-regulation. Psychological Inquiry, 11(3), 184-187.

Joreskog K.G., \& Sorbom, D. (2001). LISREL 8: User's reference guide. Chicago, IL: Scientific Software International.

Kaiser, H. F. (1961). Tops in Factor Analysis. PsycCRITIQUES, 6(10).

Kahn, J. H., \& Hessling, R. M. (2001). Measuring the tendency to conceal versus disclose psychological distress. Journal of Social and Clinical Psychology, 20(1), 41-65.

Kelly, G. (1955). A theory of personality: A psychology of personal construct. New York: Norton.

Kendall, M. G., \& Stuart, A. (1958). The advanced theory of statistics. New York: Hafner.

King, L. A., \& Emmons, R. A. (1990). Conflict over emotional expression: Psychological and physical correlates. Journal of Personality and Social Psychology, 58(5), 864-877.

Kline, R. B. (1998). Principles and practices of structural equation modeling. New York: Guilford Press.

Koole, S. L. (2009). The psychology of emotion regulation: An integrative review. Cognition and Emotion, 23(1), 4-41.

Kulik, J. A., Mahler, H. I. M., \& Earnest, A. (1994). Social comparison and affiliation under threat: Going beyond the affiliate-choice paradigm. Journal of Personality and Social Psychology, 66(2), 301-309. 
Kulik, J. A., Mahler, H. I. M., \& Moore, P. J. (1996). Social comparison and affiliation under threat: Effects on recovery from major surgery. Journal of Personality and Social Psychology, 71(5), 967-979.

Langston, C. A. (1994). Capitalizing on and coping with daily-life events: Expressive responses to positive events. Journal of Personality and Social Psychology, 67(6), $1112-1125$.

Lepore, S. J., Fernandez-Berrocal, P., Ragan, J., \& Ramos, N. (2004). It's not that bad: Social challenges to emotional disclosure enhance adjustment to stress. Anxiety, Stress \& Coping: An International Journal, 17(4), 341-361.

Luminet, O., Bouts, P., Delie, F., Manstead, A. S. R., \& Rimé, B. (2000). Social sharing of emotion following exposure to a negatively valenced situation. Cognition and Emotion, 14, 661-688.

Lyne, K., \& Roger, D. (2000). A psychometric re-assessment of the COPE questionnaire. Personality and Individual Differences, 29(2), 321-335.

Martin, L. L., \& Tesser, A. (1989). Toward a motivational and structural theory of ruminative thought. In J. S. Uleman \& J. A. Bargh (Eds.), Unintended thought. (pp. 306-326). New York: Guilford Press.

Mikulincer, M., \& Shaver, P. R. (2007). Attachment in adulthood: Structure, dynamics, and change. New York: Guilford Press.

Miller, L. C., Berg, J. H., \& Archer, R. L. (1983). Openers: Individuals who elicit intimate self-disclosure. Journal of Personality and Social Psychology, 44(6), 1234-1244.

Nils, F., Delfosse, C., \& Rimé, B. (2005). Partage social des émotions: Raisons invoquées et médiateurs perçus [Social sharing of emotions: Alleged reasons and perceived mediators]. Unpublished manuscript. University of Louvain at Louvain-la-Neuve, Belgium. 
Nils, F., \& Rimé, B. (2012). Beyond the myth of venting: Social sharing modes determine the benefits of emotional disclosure. European Journal of Social Psychology, 42(6), 672681.

Pennebaker, J. W. (1997). Writing about emotional experiences as a therapeutic process. Psychological Science, 8(3), 162-166.

Pennebaker, J.W. \& Chung, C.K. (2007). Expressive writing, emotional upheavals, and health. In H.S. Friedman \& R.C. Silver (Eds.), Foundations of health psychology (pp. 263-285). Oxford University Press.

Pett, M., Lackey, N. \& Sullivan, J. (2003). Making sense of factor analysis. Thousand Oaks: Sage Publications, Inc.

Reis, H. T., Smith, S. M., Carmichael, C. L., Caprariello, P. A., Tsai, F.F., Rodrigues, A., \& Maniaci, M. R. (2010). Are you happy for me? How sharing positive events with others provides personal and interpersonal benefits. Journal of Personality and Social Psychology, 99(2), 311-329.

Rimé, B. (1989). Le partage social des émotions. In B. Rimé \& K. Scherer (Eds.), Les émotions (pp. 271-303). Neuchâtel : Delachaux et Niestlé.

Rimé, B. (2007). Interpersonal emotion regulation. In J.J. Gross (Ed.), Handbook of emotion regulation (pp. 466-485). New York: Guilford Press.

Rimé, B. (2009). Emotion elicits the social sharing of emotion: Theory and empirical review. Emotion Review, 1, 60-85.

Rimé, B., Finkenauer, C., Luminet, O., Zech, E., \& Philippot, P. (1998). Social sharing of emotions: New evidence and new questions. In W. Stroebe \& M. Hewstone (Eds.), European Review of Social Psychology (Vol. 9, pp. 145-189). Chichester, UK: John Wiley \& Sons Ltd.

Rimé, B., Mesquita, B., Philippot, P., \& Boca, S. (1991). Beyond the emotional event: Six 
studies on the social sharing of emotion. Cognition and Emotion, 5(5-6), 435-465.

Rimé, B., Noël, P., \& Philippot, P. (1991). Episode émotionnel, réminiscences cognitives et réminiscences sociales. Cahiers Internationaux de Psychologie Sociale, 11, 93-104.

Rimé, B., Philippot, P., Boca, S., \& Mesquita, B. (1992). Long lasting cognitive and social consequences of emotion: Social sharing and rumination. In W. Stroebe \& M. Hewstone (Eds.), European Review of Social Psychology (Vol. 3, pp. 225-258). Chichester, UK: John Wiley \& Sons Ltd.

Rose, A.J. (2002). Co-rumination in the friendships of girls and boys. Child Development, 73(6), 1830-1843

Schachter, S. (1959). The psychology of affiliation. Stanford, CA: Stanford University Press.

Scherer, K.R., Wallbott, H.G., \& Summerfield, A.B. (1986). Experiencing emotion: a crosscultural study. Cambridge: Cambridge University Press.

Shaver, P., \& Klinnert, M. (1982). Schachter's theories of affiliation and emotion: Implications of developmental research. Review of Personality and Social Psychology, $3,37-71$.

Shaver, P., \& Mikulincer, M. (2002). Attachment-related psychodynamics. Attachment \& Human Development, 4(2), 133-161.

Shaver, P., Schwartz, J., Kirson, D., \& O'Connor, C. (1987). Emotion knowledge: further exploration of a prototype approach. Journal of Personality and Social Psychology, 52(6), 1061-1086.

Singh-Manoux, A., \& Finkenauer, C. (2001). Cultural variations in social sharing of emotions: An intercultural perspective. Journal of Cross-Cultural Psychology, 32, $647-661$.

Skowronski, J. J., Gibbons, J. A., Vogl, R. J., \& Walker, W. R. (2004). The effect of social disclosure on the intensity of affect provoked by autobiographical memories. Self and 
Identity, 3(4), 285-309.

Smyth, J.M., \& Pennebaker, J.W. (2008). Exploring the boundary conditions of expressive writing: In search of the right recipe. British Journal of Health Psychology, 13, 1-7.

Snell, W. E., Miller, R. S., \& Belk, S. S. (1988). Development of the Emotional SelfDisclosure Scale. Sex Roles, 18(1-2), 59-73.

Sroufe, L. A., \& Waters, E. (1976). The ontogenesis of smiling and laughter: A perspective on the organization of development in infancy. Psychological Review, 83(3), 173-189.

Stone, L. B., Hankin, B. L., Gibb, B. E., \& Abela, J. R. (2011). Co-rumination predicts the onset of depressive disorders during adolescence. Journal of abnormal psychology, 120(3), 752-757.

Tabachnick, B. \& Fidell, L. (2001). Using multivariate statistics. Needham Heights: Allyn \& Bacon.

Tomkins, S. S. (1995). Exploring affect: the selected writings of Silvan S Tomkins. Cambridge University Press.

Tzeng, O. C. (1992). On reliability and number of principal components: Joinder with Cliff and Kaiser. Perceptual and Motor Skills, 75(3, Pt 1), 929-930.

Weick, K. (1995). Sensemaking in organizations. Los Angeles, CA: SAGE.

Zech, E., \& Rimé, B. (2005). Is Talking About an Emotional Experience Helpful? Effects on Emotional Recovery and Perceived Benefits. Clinical Psychology \& Psychotherapy, 12(4), 270-287.

Zlomke, K.R., \& Hahn, K.S. (2010). Cognitive emotion regulation strategies: Gender differences and associations to worry. Personality and Individual Differences, 48, 408-413.

Zwick, W. R., \& Velicer, W. F. (1986). Comparison of five rules for determining the number of components to retain. Psychological Bulletin, 99(3), 432-442. 
Table 1.

Summary of the data from the three previous studies about alleged motives for social sharing of emotions (adapted from Rimé, 2007)

\begin{tabular}{|c|c|c|c|}
\hline $\begin{array}{c}\text { Finkenauer \& Rimé } \\
\text { (1996) }\end{array}$ & Delfosse et al. (2004) & $\begin{array}{c}\text { Nils et al. (2005, cited by } \\
\text { Rimé, 2007) }\end{array}$ & Summary of motives \\
\hline $\begin{array}{l}\text { Rehearsing: } \\
\text { reexperiencing }\end{array}$ & $\begin{array}{l}\text { Reminding: } \\
\text { reexperiencing, } \\
\text { remembering, rehearsing }\end{array}$ & & Rehearsing \\
\hline $\begin{array}{l}\text { Venting: expressing, } \\
\text { searching for relief }\end{array}$ & $\begin{array}{l}\text { Catharsis: venting, finding } \\
\text { relief, alleviating }\end{array}$ & $\begin{array}{l}\text { Affective motives: } \\
\text { catharsis, search for relief }\end{array}$ & Venting \\
\hline \multirow[t]{3}{*}{$\begin{array}{l}\text { Obtaining comfort: } \\
\text { support, listening, } \\
\text { sympathy, help }\end{array}$} & $\begin{array}{l}\text { Social support: being } \\
\text { listened to, receiving } \\
\text { help/support }\end{array}$ & $\begin{array}{l}\text { Social motives: seeking } \\
\text { help and support }\end{array}$ & Social support / help \\
\hline & & $\begin{array}{l}\text { Socioaffectives motives: } \\
\text { being consoled, comforted }\end{array}$ & Emotional social support \\
\hline & & $\begin{array}{l}\text { Social approval motives: } \\
\text { being legitimized, } \\
\text { approved, understood }\end{array}$ & $\begin{array}{c}\text { Legitimization / social } \\
\text { validation }\end{array}$ \\
\hline $\begin{array}{l}\text { Finding understanding: } \\
\text { explanation, meaning }\end{array}$ & $\begin{array}{l}\text { Understanding: analyzing } \\
\text { what happened, finding } \\
\text { meaning }\end{array}$ & $\begin{array}{l}\text { Cognitive motives: } \\
\text { cognitive clarification, } \\
\text { finding words }\end{array}$ & Cognitive clarification \\
\hline $\begin{array}{l}\text { Obtaining advice: } \\
\text { feedback, guidance }\end{array}$ & $\begin{array}{l}\text { Knowing other person's } \\
\text { view: receiving advice, } \\
\text { finding solutions }\end{array}$ & $\begin{array}{l}\text { Sociocognitive motives: } \\
\text { receiving advice, } \\
\text { suggestions, solutions }\end{array}$ & $\begin{array}{c}\text { Sociocognitive } \\
\text { clarification / } \\
\text { informative support }\end{array}$ \\
\hline
\end{tabular}


Running head: MOTIVES FOR SHARING AN EMOTIONAL EXPERIENCE

\begin{tabular}{|c|c|c|c|}
\hline $\begin{array}{l}\text { Being in touch: escaping } \\
\text { loneliness }\end{array}$ & $\begin{array}{l}\text { Social bonding: escaping } \\
\text { loneliness/feeling of } \\
\text { abandonment }\end{array}$ & $\begin{array}{l}\text { Sociorelational motives: } \\
\text { strengthening social links }\end{array}$ & $\begin{array}{c}\text { Social cohesion, bonding } \\
\text { / strengthening social } \\
\text { links }\end{array}$ \\
\hline & $\begin{array}{l}\text { Empathy: } \\
\text { touching/moving others, } \\
\text { feeling oneself closer to } \\
\text { others }\end{array}$ & $\begin{array}{l}\text { Affecting the target : } \\
\text { moving the listener }\end{array}$ & Arousing empathy \\
\hline $\begin{array}{l}\text { Receiving attention, } \\
\text { impressing others }\end{array}$ & $\begin{array}{l}\text { Gaining attention: } \\
\text { distinguishing oneself, } \\
\text { eliciting interest }\end{array}$ & & Gaining attention \\
\hline Informing others: warning & $\begin{array}{l}\text { Informing others: bringing } \\
\text { them one's experience }\end{array}$ & $\begin{array}{l}\text { Informing one's close } \\
\text { circle of one's experience } \\
\text { or of one's condition }\end{array}$ & $\begin{array}{l}\text { Informing and/or } \\
\text { warning }\end{array}$ \\
\hline
\end{tabular}


Table 2.

A list of motives alleged by respondents for sharing an emotion (from Rimé, 2007)

\section{Rehearsing}

Recalling, reexperiencing, memorizing, remembering, rehearsing

\section{Venting}

Expressing, searching for relief, getting steam off, alleviating, blowing off steam, catharsis

\section{Help and support}

Obtaining comfort, support, listening, sympathy, help, being listened at, receiving help/support/understanding, being understood

\section{Comfort/consolation}

Being consoled, comforted

\section{Legitimization}

Receiving approval, being legitimized, understood

\section{Clarification and meaning}

Understanding, finding explanation and/or meaning, analyzing what happened, finding order, gaining cognitive clarity by receiving feedback, finding words to express.

\section{Advice and solutions}

Obtaining advice, receiving guidance, knowing about another person's view, receiving advice, finding solutions

\section{Bonding}

Being in touch, relating, escaping loneliness, strengthening social links

9. Arousing empathy

Touching/moving others, affecting the target

\section{Gaining attention}

Impressing others, distinguishing oneself, eliciting interest, managing the impression that other people have of you

\section{Entertaining}

Amusing another person

\section{Informing and/or warning}

Bringing others one's experience, preventing others from making the same mistake 
Table 3.

Results of the content analysis: distribution of the 487 collected social sharing motives in the various categories

\begin{tabular}{|c|c|c|}
\hline $\begin{array}{l}\text { Social sharing } \\
\text { motives }\end{array}$ & $\begin{array}{c}n \\
(\%)\end{array}$ & typical items \\
\hline 1. Rehearsing/Brooding & $\begin{array}{c}41 \\
(8.42 \%)\end{array}$ & $\begin{array}{l}\text { "re-experiencing the moment" } \\
\text { ("revivre le moment") } \\
\text { "remembering what occurred" } \\
\text { ("me remémorer ce qui s'est passé") } \\
\text { "giving significance to the event" } \\
\text { ("donner de l'importance à l'événement") }\end{array}$ \\
\hline 2. Venting & $\begin{array}{c}132 \\
(27.11 \%)\end{array}$ & $\begin{array}{l}\text { "letting off steam" } \\
\text { ("évacuer le trop plein d'émotions") } \\
\text { "letting go of a burden" } \\
\text { ("me libérer d'un poids") } \\
\text { "externalizing emotions" } \\
\text { ("extérioriser mes émotions") }\end{array}$ \\
\hline $\begin{array}{l}\text { 3. Assistance and } \\
\text { support }\end{array}$ & & $\begin{array}{l}\text { "being comforted" } \\
\text { ("être réconforté(e)") }\end{array}$ \\
\hline Comfort & $\begin{array}{c}60 \\
(12.32 \%)\end{array}$ & $\begin{array}{l}\text { "receiving support" } \\
\text { ("être soutenu(e)") } \\
\text { "being helped" } \\
\text { ("être aidé(e)") }\end{array}$ \\
\hline $\begin{array}{l}\text { 4. Clarification and } \\
\text { meaning }\end{array}$ & $\begin{array}{c}19 \\
(3.90 \%)\end{array}$ & $\begin{array}{l}\text { "having a better understanding of what } \\
\text { occurred" } \\
\text { ("mieux comprendre ce qui s'est passé") } \\
\text { "analyzing what occurred" } \\
\text { ("analyser ce qui s'est passé") } \\
\text { "putting what occurred into perspective" } \\
\text { ("prendre du recul par rapport à ce qui s'est } \\
\text { passé") }\end{array}$ \\
\hline 5. Advice and solutions & $\begin{array}{c}58 \\
(11.91 \%)\end{array}$ & $\begin{array}{l}\text { "receiving advice" } \\
\text { (" recevoir des conseils") } \\
\text { "receiving suggestions" } \\
\text { ("recevoir des suggestions") } \\
\text { " hearing an outside perspective" } \\
\text { ("avoir un avis extérieur") }\end{array}$ \\
\hline 6. Bonding & $\begin{array}{c}25 \\
(5.13 \%)\end{array}$ & $\begin{array}{l}\text { "strengthening my social bonds" } \\
\text { ("resserrer mes liens avec l'autre") } \\
\text { "feeling the other's presence" }\end{array}$ \\
\hline
\end{tabular}




\begin{tabular}{|c|c|c|}
\hline & & $\begin{array}{l}\text { (“ sentir la présence de l’autre”) } \\
\text { "escaping from loneliness" } \\
\text { ("me sentir moins seul(e)”) }\end{array}$ \\
\hline \multirow[t]{3}{*}{ 7. Arousing empathy } & & "touching him/her" \\
\hline & & (“toucher 1'autre”) \\
\hline & 67 & "arousing empathy" \\
\hline \multirow[t]{5}{*}{ Gaining attention } & $(13.76 \%)$ & (“susciter l'empathie”) \\
\hline & & "sharing my experience" \\
\hline & & ("partager mon expérience”) \\
\hline & & "informing him/her" \\
\hline & & (“informer l’autre”) \\
\hline \multirow{4}{*}{$\begin{array}{l}\text { 8. Informing and/or } \\
\text { warning }\end{array}$} & 85 & "warning others" \\
\hline & $(17.45 \%)$ & ("avertir les autres”) \\
\hline & & "informing him/her about what occurred" \\
\hline & & ("prévenir l'autre de ce qui s’est passé”) \\
\hline
\end{tabular}


Running head: MOTIVES FOR SHARING AN EMOTIONAL EXPERIENCE

Table 4.

Comparison of positive and negative events for frequency of occurrence of the various categories of motives in respondents' answers.

\begin{tabular}{lccc}
\hline \multicolumn{1}{c}{ Motives } & $\begin{array}{c}\text { Positive event } \\
(n=193)\end{array}$ & $\begin{array}{c}\text { Negative event } \\
(n=294)\end{array}$ & $\chi^{2}(1, \mathrm{~N}=487)$ \\
\hline Rehearsing & 35 & 6 & $11.69^{*}$ \\
Venting & 32 & 100 & $98.79^{*}$ \\
Assistance, Support and Comfort & 3 & 57 & $34.30^{*}$ \\
Clarification and Meaning & 0 & 19 & $12.98^{*}$ \\
Advice and Solutions & 4 & 54 & $29.48^{*}$ \\
Bonding & 7 & 18 & 1.49 \\
Arousing Empathy/Attention & 55 & 12 & $58.54^{*}$ \\
Informing and/or Warning & 55 & 30 & $27.06^{*}$ \\
\hline
\end{tabular}

Note. ${ }^{*} p<.001$ 
Table 5 .

Loadings of the 39 items in the Seven-Factor Solution

\begin{tabular}{|c|c|c|c|c|c|c|c|}
\hline \multirow[t]{2}{*}{ Items } & \multicolumn{7}{|c|}{ Factors } \\
\hline & 1 & 2 & 3 & 4 & 5 & 6 & 7 \\
\hline toucher l'autre ("touching him/her») & & & & 0,774 & & $-0,206$ & $-0,218$ \\
\hline susciter l'intérêt («generate interest») & & & & 0,746 & & & \\
\hline émouvoir l'autre («move him/her») & & & & 0,724 & & & \\
\hline avoir l'attention portée sur moi («gain attention ») & & & & 0,685 & & & 0,226 \\
\hline être pris en considération ( «be legitimized ») & 0,311 & & & $\mathbf{0 , 5 8 6}$ & & & 0,208 \\
\hline me distinguer (« distinguish myself») & & 0,288 & & 0,421 & & 0,231 & 0,333 \\
\hline susciter l'empathie («arouse empathy ») & & & & 0,418 & & 0,227 & 0,329 \\
\hline revivre ce moment ( «re-experience this moment») & & $\mathbf{0 , 8 6 5}$ & & & & & \\
\hline me remémorer ce qui s'est passé ( remember what occurred») & 0,247 & $\mathbf{0 , 8 1 4}$ & & & & & \\
\hline partager l'événement ( «share the event ») & & 0,616 & & & 0,327 & & \\
\hline provoquer la surprise ( « cause surprise ») & & 0,612 & & 0,223 & & & \\
\hline partager mon expérience («share my experience ») & & $\mathbf{0 , 5 3 9}$ & & & & $-0,208$ & \\
\hline mieux comprendre ce qui s'était passé ( better understand what occurred ») & $\mathbf{0 , 8 0 2}$ & & & & & & \\
\hline analyser ce qui s'était passé ( « analyze what happened») & $\mathbf{0 , 7 7 0}$ & & & & & & \\
\hline trouver du sens à ce qui s'était passé ( «find meaning in what occurred») & 0,752 & & & & & & \\
\hline réfléchir à ce qui s’est passé («think about what occurred») & $\mathbf{0 , 7 4 3}$ & & & & & & \\
\hline $\begin{array}{l}\text { prendre du recul par rapport à ce qui s'était passé («put what occurred into } \\
\text { perspective ») }\end{array}$ & 0,685 & & & & & & \\
\hline $\begin{array}{l}\text { mettre de l'ordre dans mes idées à propos de ce qui s'était passé } \\
\text { («clarify my feelings about what occurred ») }\end{array}$ & 0,636 & & 0,205 & & & & \\
\hline exprimer mes émotions ( « express my emotions ») & & & $\mathbf{0 , 8 7 3}$ & & & & \\
\hline partager mes émotions ( « share my emotions ») & & 0,213 & 0,816 & & & & \\
\hline déballer ce que j'avais sur le cœur ( express repressed resentment ») & & $-0,225$ & 0,681 & & & & \\
\hline évacuer le trop plein d'émotions ( let off steam ») & & & 0,662 & & & & \\
\hline extérioriser mes émotions («let my emotions out ») & & & 0,650 & & & & 0,235 \\
\hline
\end{tabular}


vider mon sac ( get it off my chest »)

0,205

$-0,216$

$\mathbf{0 , 5 4 7}$

0,257

prévenir l'autre de ce qui c'est passé («inform him/her about what

occurred »)

informer de la nouvelle situation («inform him/her about the situation»)

$\mathbf{0 , 7 6 3}$

avertir les autres ( warn others »)

informer l'autre ( inform others »)

$-0,202 \quad 0,288$

$0,371-0,312$

0,676

mettre en garde l'autre ( $"$ warn him/her »)

$0,371-0,312$

être entouré(e) («be surrounded»)

être épaulé(e) ( « be supported »)

sentir que je pouvais compter sur quelqu'un («feel I could rely on

somebody»)

être aidé(e) («be helped»)

être soutenu(e) (« receive support »)

avoir l'opinion de l'autre («learn about his/her opinion»)

savoir ce que l'autre en pense ( learn bout his/her view»)

avoir un avis extérieur ( get an outside perspective »)

recevoir des suggestions («receive suggestions »)

voir comment l'autre aurait réagi ( see how he/she would have reacted»)

$\mathbf{0 , 7 9 0}$

$\mathbf{0 , 7 5 1}$

0,663

$-0,316 \mathbf{0 , 6 3 1}$

0,614

$-0,667$

$\mathbf{- 0 , 6 5 9}$

$-0,653$

$\mathbf{- 0 , 5 8 6} 0,323$

$-\mathbf{0 , 4 3 1}$

Note. $\mathrm{N}=382$, Extraction: principal axis factoring method, Rotation: oblimin method. Loadings above 0.30 are shown in boldface. For the sake of readability, loadings below 0.20 are not shown. 
Running head: MOTIVES FOR SHARING AN EMOTIONAL EXPERIENCE

Table 6.

Properties of the seven subscales of the SSMS and their intercorrelations

\begin{tabular}{|c|c|c|c|c|c|c|c|c|c|c|c|}
\hline & M & $\mathrm{SD}$ & $\begin{array}{l}\mathrm{N} \text { of } \\
\text { items }\end{array}$ & $\alpha$ & $\mathrm{F} 1$ & $\mathrm{~F} 2$ & F3 & $\mathrm{F} 4$ & F5 & F6 & F7 \\
\hline F1. Clarification/Meaning & 12,69 & 7,08 & 6 & 0.82 & -- & & & & & & \\
\hline F2. Rehearsing & 14,15 & 8,03 & 5 & 0.84 & 0,46 & -- & & & & & \\
\hline F3. Venting & 18,31 & 10,38 & 6 & 0.90 & 0,25 & 0,02 & -- & & & & \\
\hline F4. Arousing Empathy/Attention & 26,26 & 9,96 & 7 & 0.86 & $\mathbf{0 , 1 7}$ & 0,03 & 0,48 & -- & & & \\
\hline F5. Informing and/or Warning & 14,24 & 7,12 & 5 & 0.75 & $\mathbf{0 , 3 9}$ & $\mathbf{0 , 3 4}$ & 0,25 & 0,14 & -- & & \\
\hline $\begin{array}{l}\text { F6. Assistance/Support and } \\
\text { Comfort/Consolation }\end{array}$ & 15,65 & 9,72 & 5 & 0.92 & $\mathbf{0 , 2 0}$ & $-0,16$ & $\mathbf{0 , 5 9}$ & 0,60 & 0,17 & -- & \\
\hline F7. Advice/Solutions & 18,26 & 8,44 & 5 & 0.84 & 0,31 & 0,11 & 0,65 & 0,45 & 0,34 & 0,57 & -- \\
\hline
\end{tabular}

Note. Bravais-Pearson's $r(N=720)$. Correlations in boldface $p<.001$. 
Running head: MOTIVES FOR SHARING AN EMOTIONAL EXPERIENCE

Table 7.

Motives of social sharing by emotional event condition (means and standard deviation).

Emotional Event Condition $(N=719)$

\begin{tabular}{|c|c|c|c|c|c|}
\hline & \\
\hline & $\begin{array}{l}\text { Anger } \\
(n=193)\end{array}$ & $\begin{array}{l}\text { Joy } \\
(n=193)\end{array}$ & $\begin{array}{l}\text { Fear } \\
(n=167)\end{array}$ & $\begin{array}{l}\text { Sadness } \\
(n=166)\end{array}$ & $F_{(3,715)}$ \\
\hline \multirow[t]{2}{*}{ Clarification/Meaning } & $3.69 \mathrm{a}$ & $2.10 \mathrm{~b}$ & $2.98 \mathrm{c}$ & $3.47 \mathrm{a}$ & \multirow[t]{2}{*}{$35.95 * * *$} \\
\hline & $(1.75)$ & $(1.35)$ & $(1.64)$ & $(1.71)$ & \\
\hline \multirow{2}{*}{ Rehearsing } & $2.19 \mathrm{c}$ & $4.44 \mathrm{a}$ & $2.49 \mathrm{c}$ & $2.04 \mathrm{~b}$ & \multirow{2}{*}{$145.33 * *$} \\
\hline & $(1.13)$ & $(1.43)$ & $(1.35)$ & $(1.11)$ & \\
\hline \multirow{2}{*}{ Venting } & $4.75 \mathrm{a}$ & $3.78 b$ & $4.25 b$ & $4.77 \mathrm{a}$ & \multirow{2}{*}{$15.82 * *$} \\
\hline & $(1.74)$ & $(1.39)$ & $(1.66)$ & $(1.65)$ & \\
\hline \multirow{2}{*}{ Arousing Empathy/Attention } & $1.72 b$ & $2.03 \mathrm{a}$ & $1.69 \mathrm{~b}$ & $1.78 \mathrm{ab}$ & \multirow{2}{*}{$4.50 *$} \\
\hline & $(.97)$ & $(1.02)$ & $(1.02)$ & $(1.03)$ & \\
\hline \multirow{2}{*}{ Informing and/or Warning } & 2.88 & 2.89 & 2.98 & 2.61 & \multirow{2}{*}{2.16} \\
\hline & $(1.48)$ & $(1.35)$ & $(1.49)$ & $(1.36)$ & \\
\hline Assistance/Support and & $3.48 \mathrm{a}$ & 1.85 & $3.25 \mathrm{a}$ & $4.10 b$ & $53.44 * *$ \\
\hline Comfort/Consolation & $(1.83)$ & $(1.35)$ & $(1.97)$ & $(1.89)$ & \\
\hline \multirow{2}{*}{ Advice/Solutions } & $4.25 b$ & $3.10 \mathrm{a}$ & $3.47 \mathrm{abc}$ & $3.81 b$ & \multirow{2}{*}{$17.03 * *$} \\
\hline & $(1.56)$ & $(1.65)$ & $(1.69)$ & $(1.66)$ & \\
\hline
\end{tabular}

Note. ${ }^{*} p<.01 ; * * p<.001$ 
Running head: MOTIVES FOR SHARING AN EMOTIONAL EXPERIENCE

Table 8.

Motives of social sharing by gender (mean and standard deviation)

$\begin{array}{ccc}\text { Female } & \text { Male } & F_{(1,717)} \\ (n=496) & (n=223) & \end{array}$

Clarification/Meaning

$3.16(1.79)$

$2.83(1.58)$

$5.54 * *$

Rehearsing

$2.75(1.59)$

$3.01(1.62)$

$4.15^{*}$

Venting

$4.68(1.59)$

$3.70(1.63)$

$56.766^{* * *}$

Arousing

empathy/Attention

$1.70(.93)$

$2.06(1.15)$

$20.27 * * *$

Informing and/or Warning

$3.05(1.55)$

$6.66^{* *}$

Assistance/Support and

$3.39(1.99) \quad 2.55(1.72) \quad 26.56^{* * *}$

Comfort/Consolation

Advice/Solutions

$3.80(1.73)$

$3.33(1.56)$

$12.33 * *$

Note. $* p<.05 ; * * p<.01 ; * * * p<.0001$ 
Running head: MOTIVES FOR SHARING AN EMOTIONAL EXPERIENCE

Table 9. Correlations between the intensity of the emotional episode, the parameters of social sharing (delay, frequency, number of persons) and the alleged motives for social sharing $(n=719)$

\begin{tabular}{|c|c|c|c|c|}
\hline & Intensity & Latency & Frequency & $\begin{array}{c}\text { Number } \\
\text { of } \\
\text { sharing } \\
\text { partners }\end{array}$ \\
\hline Clarification/Meaning & $.094 * *$ & .038 & .005 & $-.079 *$ \\
\hline Rehearsing & $.094 * *$ & $-.169 * *$ & $.294 * *$ & $.335^{* *}$ \\
\hline Venting & $.273 * *$ & -.036 & $.101^{* *}$ & -.013 \\
\hline Arousing Empathy/Attention & .044 & -.048 & $.159^{* *}$ & $.109 * *$ \\
\hline Informing and/or Warning & .041 & $-.161^{* *}$ & $.190^{* *}$ & $.253 * *$ \\
\hline $\begin{array}{l}\text { Assistance/Support and } \\
\text { Comfort/Consolation }\end{array}$ & $.160 * *$ & .045 & .044 & -.052 \\
\hline Advice/Solutions & .002 & -.055 & .051 & -.018 \\
\hline
\end{tabular}

Note. $* p<.05, * * p<.01$ 
Running head: MOTIVES FOR SHARING AN EMOTIONAL EXPERIENCE

Table 10.

Motives of social sharing by type of sharing partner (mean and standard deviation)

\begin{tabular}{|c|c|c|c|c|c|}
\hline & $\begin{array}{l}\text { Companion } \\
\qquad(n=164)\end{array}$ & $\begin{array}{c}\text { Friend } \\
(n=281)\end{array}$ & $\begin{array}{l}\text { Family } \\
\text { member } \\
(n=231)\end{array}$ & $\begin{array}{l}\text { Non intimate } \\
\qquad(n=43)\end{array}$ & $F_{3,715}$ \\
\hline Clarification/meaning & $3.01(1.75)$ & $3.10(1.79)$ & $3.03(1.68)$ & $2.91(1.55)$ & .217 \\
\hline Rehearsing & $2.69(1.60)$ & $2.77(1.58)$ & $3.04(1.67)$ & $2.60(1.38)$ & 2.18 \\
\hline Venting & $4.38(1.68) \mathrm{a}$ & $4.49(1.63) \mathrm{a}$ & $4.35(1.64) \mathrm{a}$ & $3.71(1.83) b$ & $2.80 *$ \\
\hline $\begin{array}{l}\text { Arousing } \\
\text { empathy/attention }\end{array}$ & $1.76(0.97)$ & $1.84(1.05)$ & $1.80(0.99)$ & $1.88(0.99)$ & .301 \\
\hline $\begin{array}{l}\text { Informing and/or } \\
\text { warning }\end{array}$ & $2.73(1.38)$ & $2.77(1.38)$ & $3.02(1.46)$ & $2.74(1.62)$ & 1.96 \\
\hline $\begin{array}{l}\text { Assistance/support } \\
\text { and Help/consolation }\end{array}$ & $3.08(1.81) \mathrm{ab}$ & $3.37(2.07) \mathrm{a}$ & $2.99(1.88) b$ & $2.44(1.77) b$ & $3.64 *$ \\
\hline Advice/Solutions & $3.45(1.69)$ & $3.79(1.71)$ & $3.66(1.66)$ & $3.36(1.67)$ & 1.83 \\
\hline
\end{tabular}

Note. $* p<.05$ 
Table 11.

Comparison between the results of the present study and those of the three previous studies about alleged motives for social sharing

\begin{tabular}{|c|c|c|c|}
\hline $\begin{array}{c}\text { Finkenauer \& Rimé } \\
(\mathbf{1 9 9 6 )}\end{array}$ & Delfosse et al. (2004) & $\begin{array}{c}\text { Nils et al. (2005, cited by } \\
\text { Rimé, 2007) }\end{array}$ & The present study \\
\hline $\begin{array}{l}\text { Rehearsing: } \\
\text { reexperiencing }\end{array}$ & $\begin{array}{l}\text { Reminding: } \\
\text { reexperiencing, } \\
\text { remembering, rehearsing }\end{array}$ & & rehearsing \\
\hline $\begin{array}{l}\text { Venting: expressing, } \\
\text { searching for relief }\end{array}$ & $\begin{array}{l}\text { Catharsis: venting, finding } \\
\text { relief, alleviating }\end{array}$ & $\begin{array}{l}\text { Affective motives: } \\
\text { catharsis, search for relief }\end{array}$ & venting \\
\hline \multirow[t]{3}{*}{$\begin{array}{l}\text { Obtaining comfort: } \\
\text { support, listening, } \\
\text { sympathy, help }\end{array}$} & $\begin{array}{l}\text { Social support: being } \\
\text { listened to, receiving } \\
\text { help/support }\end{array}$ & $\begin{array}{l}\text { Social motives: seeking } \\
\text { help and support }\end{array}$ & \multirow{3}{*}{$\begin{array}{l}\text { Assistance/support and } \\
\text { Help/consolation }\end{array}$} \\
\hline & & $\begin{array}{l}\text { Socioaffectives motives: } \\
\text { being consoled, comforted }\end{array}$ & \\
\hline & & $\begin{array}{l}\text { Social approval motives: } \\
\text { being legitimized, } \\
\text { approved, understood }\end{array}$ & \\
\hline $\begin{array}{l}\text { Finding understanding: } \\
\text { explanation, meaning }\end{array}$ & $\begin{array}{l}\text { Understanding: analyzing } \\
\text { what happened, finding } \\
\text { meaning }\end{array}$ & $\begin{array}{l}\text { Cognitive motives: } \\
\text { cognitive clarification, } \\
\text { finding words }\end{array}$ & Clarification/meaning \\
\hline $\begin{array}{l}\text { Obtaining advice: } \\
\text { feedback, guidance }\end{array}$ & $\begin{array}{l}\text { Knowing other person's } \\
\text { view: receiving advice, } \\
\text { finding solutions }\end{array}$ & $\begin{array}{l}\text { Sociocognitive motives: } \\
\text { receiving advice, } \\
\text { suggestions, solutions }\end{array}$ & Advices/Solutions \\
\hline
\end{tabular}


Running head: MOTIVES FOR SHARING AN EMOTIONAL EXPERIENCE

\begin{tabular}{llll}
\hline $\begin{array}{l}\text { Being in touch: escaping } \\
\text { loneliness }\end{array}$ & $\begin{array}{l}\text { Social bonding: escaping } \\
\text { loneliness/feeling of } \\
\text { abandonment }\end{array}$ & $\begin{array}{l}\text { Sociorelational motives: } \\
\text { strengthening social links }\end{array}$ & \\
\hline & $\begin{array}{l}\text { Empathy: } \\
\text { touching/moving others, } \\
\text { feeling oneself closer to } \\
\text { others }\end{array}$ & $\begin{array}{l}\text { Affecting the target : } \\
\text { moving the listener }\end{array}$ & $\begin{array}{c}\text { Arousing } \\
\text { empathy/attention }\end{array}$ \\
\hline $\begin{array}{llll}\text { Receiving attention, } \\
\text { impressing others }\end{array}$ & $\begin{array}{l}\text { Gaining attention: } \\
\text { distinguishing oneself, } \\
\text { eliciting interest }\end{array}$ & $\begin{array}{l}\text { Informing one's close } \\
\text { circle of one's experience } \\
\text { or of one's condition }\end{array}$ & $\begin{array}{l}\text { Informing and/or } \\
\text { warning }\end{array}$ \\
\hline Informing others: warning & $\begin{array}{l}\text { Informing others: bringing } \\
\text { them one's experience }\end{array}$ & & \\
\hline
\end{tabular}




\section{Running head: MOTIVES FOR SHARING AN EMOTIONAL EXPERIENCE}

Appendix 1. Motives for Social Sharing Scale (SSMS-39)

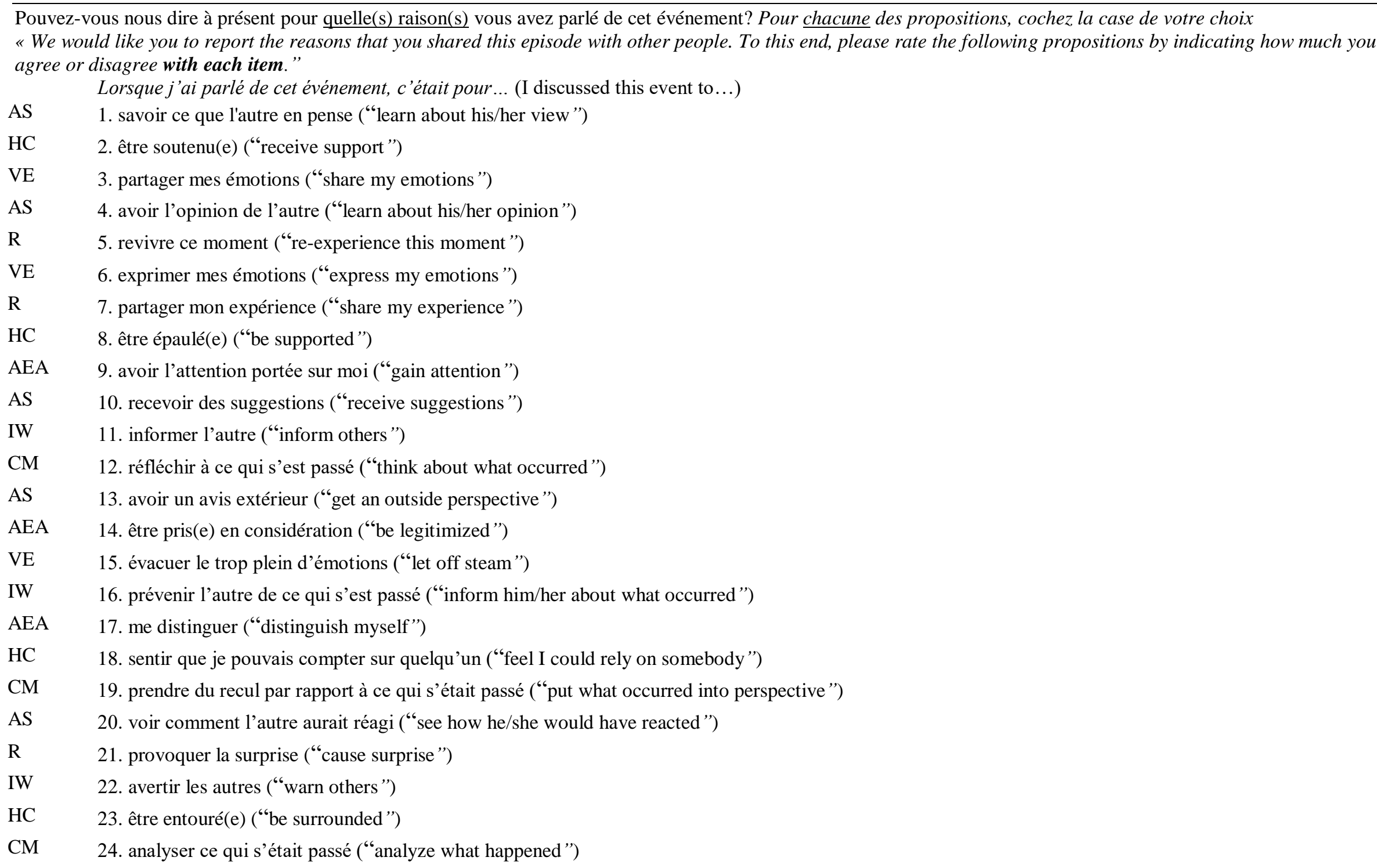


Running head: MOTIVES FOR SHARING AN EMOTIONAL EXPERIENCE

$\mathrm{R} 25$. me remémorer ce qui s'est passé ("remember what occurred")

AEA 26. susciter l'empathie ("arouse empathy")

CM 27. mieux comprendre ce qui s'était passé ("better understand what occurred")

HC 28. être aidé(e) ("be helped")

VE 29. vider mon sac ("get it off my chest")

IW 30. informer de la situation ("inform him/her about the situation")

AEA 31. toucher, attendrir l'autre ("touching him/her")

VE 32. déballer ce que j'avais sur le cœur ("express repressed resentment")

AEA 33. susciter l'intérêt ("generate interest")

CM 34. trouver du sens à ce qui s'était passé ("find meaning in what occurred")

IW 35. mettre en garde l'autre ("warn him/her")

VE 36. extérioriser mes émotions ("let my emotions out")

AEA 37. émouvoir l'autre ("move him/her")

CM 38. mettre de l'ordre dans mes idées à propos de ce qui s'était passé (“clarify my feelings about what occurred")

R 39. partager l'événement ("share the event")

Note: Each item was given a response on a 7 -point scale $(1=$ not at all; $7=$ very much).

Codification $: \mathrm{CM}=$ Clarification/Meaning $; \mathrm{R}=$ Rehearsing $; \mathrm{VE}=$ Venting $; \mathrm{AEA}=$ Arousing Empathy/Attention $; \mathrm{IW}=$ Informing $/$ Warning $;$ HC = Assistance, Support, and Comfort/Consolation, AS = Advice/Solutions 